\title{
Impact of Standing Water on Saltstone Placement II - Hydraulic Conductivity Data
}

\author{
A. D. Cozzi \\ B. R. Pickenheim
}

October 2012

Savannah River National Laboratory Savannah River Nuclear Solutions, LLC Aiken, SC 29808

Prepared for the U.S. Department of Energy under contract number DE-AC09-08SR22470. 
SRNL-STI-2012-00576

Revision 0

\section{DISCLAIMER}

This work was prepared under an agreement with and funded by the U.S. Government. Neither the U.S. Government or its employees, nor any of its contractors, subcontractors or their employees, makes any express or implied:

1. warranty or assumes any legal liability for the accuracy, completeness, or for the use or results of such use of any information, product, or process disclosed; or

2. representation that such use or results of such use would not infringe privately owned rights; or

3. endorsement or recommendation of any specifically identified commercial product, process, or service.

Any views and opinions of authors expressed in this work do not necessarily state or reflect those of the United States Government, or its contractors, or subcontractors.

\section{Printed in the United States of America}

Prepared for

U.S. Department of Energy 
Keywords: Saltstone, Saltstone

Disposal Unit

Retention: Permanent

\title{
Impact of Standing Water on Saltstone Placement II - Hydraulic Conductivity Data
}

\author{
A. D. Cozzi \\ B. R. Pickenheim
}

October 2012

Savannah River National Laboratory Savannah River Nuclear Solutions, LLC Aiken, SC 29808

Prepared for the U.S. Department of Energy under contract number DE-AC09-08SR22470. 


\section{REVIEWS AND APPROVALS}

AUTHORS:

A. D. Cozzi, Engineering Process Development

Date

B. R. Pickenheim, Engineering Process Development

Date

TECHNICAL REVIEW:

P. M. Almond, Engineering Process Development

Date

APPROVAL:

K. M. Fox, Manager

Date

Engineering Process Development

S. L. Marra, Manager

Date

Environmental \& Chemical Process Technology Research Programs

J. S. Contardi, Manager

Date

Saltstone Facility Engineering 


\section{EXECUTIVE SUMMARY}

The amount of water present during placement and subsequent curing of saltstone has the potential to impact several properties important for grout quality. An active drain water system can remove residual standing water and expose the surface of the placed saltstone to air. Oxidation of the saltstone may result in an increase in the leachability of redox sensitive elements. A dry surface can lead to cracking, causing an increase in hydraulic conductivity. An inactive drain water system can allow standing water that generates unnecessary hydrostatic head on the vault walls. Standing water that cannot be removed via the drain system will be available for potential incorporation into subsequent grout placements.

The objective of this work is to study the impact of standing water on grout quality pertaining to disposal units. A series of saltstone mixes was prepared and cured at ambient temperature to evaluate the impact of standing water on saltstone placement. The samples were managed to control drying effects on leachability by either exposing or capping the samples. The water to premix ratio was varied to represent a range of processing conditions. Samples were analyzed for density, leachability, and hydraulic conductivity. Report SRNL-STI-2012-00546 was issued detailing the experimental procedure, results, and conclusions related to density and leachability.

In the previous report, it was concluded that:

- Density tends to increase toward the bottom of the samples. This effect is pronounced with excess bleed water.

- Drying of the saltstone during curing leads to decreased Leachability Index (more leaching) for potassium, sodium, rhenium, nitrite, and nitrate.

- There is no noticeable effect on saltstone oxidation/leachability by changing the water to premix ratio (over the range studied), or by pouring into standing water (when tested up to 10 volume percent).

The hydraulic conductivity data presented in this report show that samples cured exposed to the atmosphere had about three orders of magnitude higher hydraulic conductivity than any of the other samples. Considering these data, along with the results presented in the previous report, leads to the conclusion that small changes in water to premix ratio and the inclusion of up to 10 volume percent standing water should not be expected to have a detrimental effect on saltstone grout quality. The hydraulic conductivity results further demonstrate that curing in a moist environment is critical to maintaining saltstone quality. 


\section{TABLE OF CONTENTS}

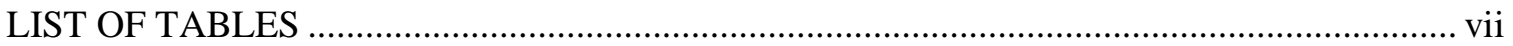

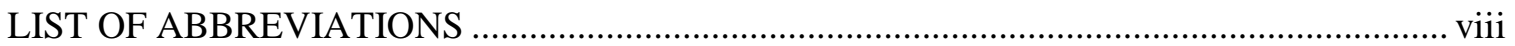

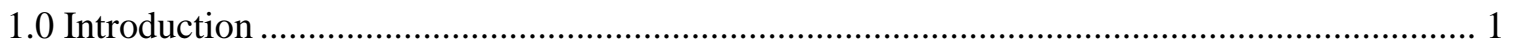

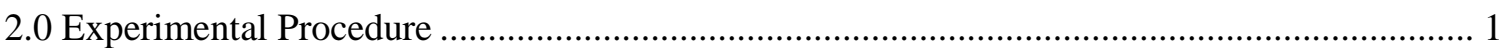

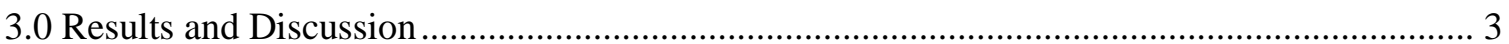

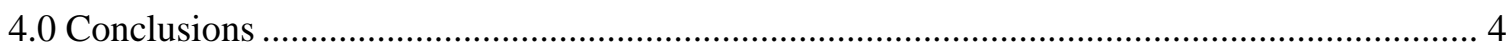

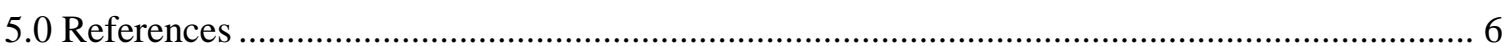




\section{LIST OF TABLES}

Table 2-1. Simulant Salt Solution Based on CY11 WAC Analysis .............................................. 2

Table 2-2. Test Conditions to Evaluate the Effect of Placing Saltstone into Standing Water........ 3

Table 3-1. Hydraulic Conductivity Results ................................................................................ 4 


\section{LIST OF ABBREVIATIONS}

$\begin{array}{ll}\text { PA } & \text { Performance Assessment } \\ \text { SDF } & \text { Saltstone Disposal Facility } \\ \text { SDU } & \text { Saltstone Disposal Unit } \\ \text { SFT } & \text { Saltstone Feed Tank } \\ \text { SPF } & \text { Saltstone Production Facility } \\ \text { SRNL } & \text { Savannah River National Laboratory } \\ \text { SRR-WSE } & \text { Savannah River Remediation - Waste Solidification Engineering } \\ \text { TS } & \text { Total Solids } \\ \text { TTQAP } & \text { Task Technical and Quality Assurance Plan } \\ \text { TTR } & \text { Technical Task Request } \\ \text { w/p } & \text { Water to premix ratio } \\ \text { WAC } & \text { Waste Acceptance Criteria }\end{array}$


SRNL-STI-2012-00576

Revision 0

\subsection{Introduction}

Prior to 2003 in Vault 4, excess water that accumulated between the saltstone grout and the vault wall was removed by drain valves into carboys and returned to the Saltstone Feed Tank (SFT). The removal of water was intended to relieve the Saltstone Disposal Facility (SDF) of the hydrostatic head pressure between the saltstone grout and the vault wall. ${ }^{1}$ A sheet drain system was added in 2003 to the SDF to facilitate the removal of water with a greater associated concentration of radionuclides. The current drain water collection system has not maintained the operational availability necessary to support the Saltstone Production Facility (SPF) throughput. ${ }^{2}$

The presence, or absence, of a moist environment for the curing of saltstone has the potential to impact several properties of the emplaced product. An active drain water system can remove residual standing water and expose the surface of the placed saltstone to air. Oxidation of the saltstone may result in an increase in the leachability of redox sensitive elements. A dry surface can lead to cracking, causing an increase in hydraulic conductivity. An inactive drain water system can generate unnecessary hydrostatic head on the vault walls and standing water that cannot be removed via the drain system and will be available for potential incorporation into subsequent grout placements.

Savannah River Remediation-Waste Solidification Engineering (SRR-WSE) has requested through a Task Technical Request (TTR) that the Savannah River National Laboratory determine the impacts of the availability of the sheet drain on select properties of placed saltstone. ${ }^{3}$ This work was performed under the guidance of a Task Technical and Quality Assurance Plan (TTQAP). ${ }^{4}$

A report has been issued detailing the experimental procedure, results, and conclusions related to density and leachability. ${ }^{5}$ The purpose of this document is to report and analyze the hydraulic conductivity data that were unavailable at the time of the publication of the previous document.

\subsection{Experimental Procedure}

A simplified salt solution was made based on the CY11 Waste Acceptance Criteria (WAC) analysis of Tank $50 \mathrm{H}^{6}$ with elevated quantities $(1000 \mathrm{mg} / \mathrm{L})$ of chromium and rhenium as surrogates for technetium-99 (Table 2-1). The salt solution has total weight percent solids (TS) of $25.13 \%$ and a density of $1.207 \mathrm{~g} / \mathrm{ml}$. 
SRNL-STI-2012-00576

Revision 0

Table 2-1. Simulant Salt Solution Based on CY11 WAC Analysis

\begin{tabular}{|c|c|c|c||}
\hline Compound & g/L & Component & M \\
\hline Water & balance & $\mathrm{Na}$ & $4.42 \mathrm{E}+00$ \\
\hline $\mathrm{KNO}_{3}$ & 0.55 & $\mathrm{Al}$ & $1.12 \mathrm{E}-01$ \\
\hline $\mathrm{NaNO}_{3}$ & 154.37 & $\mathrm{Cr}$ & $1.91 \mathrm{E}-02$ \\
\hline $\mathrm{NaOH}(50 \%)$ & 142.40 & $\mathrm{Re}$ & $5.31 \mathrm{E}-03$ \\
\hline $\mathrm{Al}\left(\mathrm{NO}_{3}\right)_{3} \cdot 9 \mathrm{H}_{2} \mathrm{O}$ & 42.01 & $\mathrm{~B}$ & $1.10 \mathrm{E}-02$ \\
\hline $\mathrm{NaNO}_{2}$ & 25.66 & $\mathrm{~K}$ & $5.40 \mathrm{E}-03$ \\
\hline $\mathrm{Na}_{2} \mathrm{CO}_{3}$ & 14.73 & $\mathrm{NO}_{3}$ & $2.16 \mathrm{E}+00$ \\
\hline $\mathrm{Na}_{2} \mathrm{SO}_{4}$ & 6.59 & $\mathrm{NO}_{2}$ & $3.70 \mathrm{E}-01$ \\
\hline $\mathrm{Na}_{2} \mathrm{CrO}_{4}$ & 3.12 & $\mathrm{OH}_{3}$ & $1.80 \mathrm{E}+00$ \\
\hline $\mathrm{Na}_{3} \mathrm{PO}_{4} \cdot 12 \mathrm{H}_{2} \mathrm{O}$ & 1.91 & $\mathrm{CO}_{3}$ & $1.40 \mathrm{E}-01$ \\
\hline $\mathrm{NaReO}_{4}$ & 1.47 & $\mathrm{SO}_{4}$ & $4.60 \mathrm{E}-02$ \\
\hline $\mathrm{Na}_{2} \mathrm{C}_{2} \mathrm{O}_{4}$ & 1.24 & $\mathrm{C}_{2} \mathrm{O}_{4}$ & $9.30 \mathrm{E}-03$ \\
\hline $\mathrm{H}_{3} \mathrm{BO}_{3}$ & 0.71 & $\mathrm{Cl}$ & $4.60 \mathrm{E}-03$ \\
\hline $\mathrm{NaCl}^{\mid}$ & 0.27 & & \\
\hline \multicolumn{3}{|l|}{} \\
\hline
\end{tabular}

A series of saltstone mixes were prepared as in previous studies ${ }^{7}$, cast into duplicate molds, and cured at ambient temperature. Cylindrical 3" x 6” (nominal) samples were prepared for hydraulic conductivity testing. The samples were managed to control drying effects by either exposing or capping the samples. Samples to be exposed were cast into steel molds, demolded after seven days, and set out exposed to ambient conditions in the laboratory. Samples to be maintained as moist were cast in plastic cylinders and capped. The water to premix (w/p) ratio was varied to represent the different processing conditions described in the TTR. ${ }^{3}$

Table 2-2 shows the different placement conditions that were evaluated. Further descriptions of each test are provided below:

1. $0.60 \mathrm{w} / \mathrm{p}$. Sample is poured into empty cylinder and cured exposed to the atmosphere.

2. $0.60 \mathrm{w} / \mathrm{p}$. Sample is poured into empty cylinder and is cured in a humid atmosphere.

3. $0.60 \mathrm{w} / \mathrm{p}$. Sample is poured into empty cylinder and is cured with 5 volume \% excess water added after gel.

4. $\quad 0.60 \mathrm{w} / \mathrm{p}$. Sample is poured into cylinder containing salt solution equal to 10 volume $\%$ of the salt solution in the mix and cured in a humid atmosphere.

5. $0.64 \mathrm{w} / \mathrm{p}$. Sample is poured into empty cylinder and is cured exposed to the atmosphere.

6. $0.64 \mathrm{w} / \mathrm{p}$. Sample is poured into empty cylinder and is cured in a humid atmosphere.

7. $0.64 \mathrm{w} / \mathrm{p}$. Sample is poured into cylinder containing salt solution equal to 5 volume $\%$ of the salt solution in the mix and cured in a humid atmosphere. 
8. $\quad 0.64 \mathrm{w} / \mathrm{p}$. Sample is poured into cylinder containing salt solution equal to 10 volume $\%$ of the salt solution in the mix and cured in a humid atmosphere.

Table 2-2. Test Conditions to Evaluate the Effect of Placing Saltstone into Standing Water

\begin{tabular}{|c|c|c|c|c||}
\hline Test & w/p & Height & Standing Water (salt solution) & Cure Conditions \\
\hline 1 & 0.60 & 0 & None & Fully Exposed \\
\hline 2 & 0.60 & 0 & None & Sealed \\
\hline 3 & 0.60 & $7.4 \mathrm{~mm}^{*}$ & $\begin{array}{c}33.9 \mathrm{ml} \text { added after placement } \\
\text { (4.7 g for small monoliths) }\end{array}$ & Sealed \\
\hline 4 & 0.60 & $14.9 \mathrm{~mm}^{\dagger}$ & $\begin{array}{c}67.8 \mathrm{ml} \text { added before placement } \\
\text { (9.4 g for small monoliths) }\end{array}$ & Sealed \\
\hline 5 & 0.64 & 0 & None & Fully Exposed \\
\hline 6 & 0.64 & 0 & Sealed \\
\hline 7 & 0.64 & $7.4 \mathrm{~mm}^{*}$ & $\begin{array}{c}33.9 \mathrm{ml} \text { added before placement } \\
(4.7 \mathrm{~g} \text { for small monoliths) }\end{array}$ & Sealed \\
\hline 8 & 0.64 & $14.9 \mathrm{~mm}^{\dagger}$ & $\begin{array}{c}67.8 \mathrm{ml} \text { added before placement } \\
(9.4 \text { for small monoliths })\end{array}$ & Sealed \\
\hline
\end{tabular}

*Corresponds to 5 volume \% bleed calculated from total volume of pour.

†Corresponds to 10 volume \% bleed calculated from total volume of pour.

The transport of water through saltstone is an input parameter to the numerical model that supports the saltstone Performance Assessment (PA). ${ }^{8}$ The saltstone PA supports the satisfaction of DOE Order 435.1, "Radioactive Waste Management." Samples from each of the test conditions were measured to determine the effect of the saltstone placement on the hydraulic conductivity. Hydraulic conductivity was measured by AMEC in Atlanta, GA by ASTM D 5084 Method F. ${ }^{9}$

\subsection{Results and Discussion}

Permeability is defined as the property that governs the rate of flow of a fluid into a porous solid. For steady-state flow, the coefficient of permeability or hydraulic conductivity (K), is determined by Darcy's Equation:

Where $d q / d t$ is the rate of fluid flow, $\mu$ is the viscosity of the fluid, $\Delta H$ is the pressure gradient, $A$ is the surface area, and $L$ is the thickness of the solid.

After curing for 28 days, the samples were cut in half to make two 3" x 3" cylinders. The saturated hydraulic conductivity was then measured on the top and bottom of each sample to determine if the previously observed density gradients ${ }^{5}$ had an effect on the hydraulic conductivity. The data are included in Table 3-1. 
Table 3-1. Hydraulic Conductivity Results

\begin{tabular}{|c|c|c|c|c|c||}
\hline Test & w/p & $\begin{array}{c}\text { Standing Water } \\
\text { (salt solution) }\end{array}$ & Cure Conditions & $\begin{array}{c}\text { Hydraulic } \\
\text { Conductivity } \\
\text { (Top) } \mathbf{( c m} / \mathbf{s})\end{array}$ & $\begin{array}{c}\text { Hydraulic } \\
\text { Conductivity } \\
\text { (Bottom) (cm/s) }\end{array}$ \\
\hline 1 & 0.60 & None & Fully Exposed & $3.5 \mathrm{E}-07$ & $2.2 \mathrm{E}-07$ \\
\hline 2 & 0.60 & None & Sealed & $1.4 \mathrm{E}-09$ & $2.5 \mathrm{E}-10$ \\
\hline 3 & 0.60 & $5 \mathrm{vol} \%$ & Sealed & $4.8 \mathrm{E}-10$ & $1.4 \mathrm{E}-10$ \\
\hline 4 & 0.60 & $10 \mathrm{vol} \%$ & Sealed & $5.0 \mathrm{E}-10$ & $2.9 \mathrm{E}-10$ \\
\hline 5 & 0.64 & None & Fully Exposed & $4.3 \mathrm{E}-07$ & $3.0 \mathrm{E}-07$ \\
\hline 6 & 0.64 & None & Sealed & $9.7 \mathrm{E}-10$ & $4.6 \mathrm{E}-10$ \\
\hline 7 & 0.64 & 5 vol \% & Sealed & $4.3 \mathrm{E}-10$ & $3.1 \mathrm{E}-10$ \\
\hline 8 & 0.64 & $10 \mathrm{vol} \%$ & Sealed & $4.1 \mathrm{E}-10$ & $4.2 \mathrm{E}-10$ \\
\hline
\end{tabular}

The samples that were demolded and cured exposed to the atmosphere (Samples 1 and 5) have larger hydraulic conductivity values compared to the other samples. Neither changing the water to premix ratio nor the inclusion of standing water had a discernible effect on hydraulic conductivity.

All the samples except for test 8 have lower hydraulic conductivity on the bottom section than the top section. By the ASTM procedure, ${ }^{9}$ each reported value is actually the average of five to seven duplicate measurements. An analysis of variance on the total data set shows that the difference between top and bottom is statistically significant at the 95\% confidence level for samples $1,2,3,5$, and 6 . This supports the earlier observation that some settling occurred in these samples, creating a denser, less permeable, material at the bottom of the mold. However, although the difference between top and bottom is detectable, its effect on overall product quality is not expected to meaningful compared to the large variation in hydraulic conductivity that can be caused by curing conditions.

\subsection{Conclusions}

A series of Saltstone mixes was prepared, cast into duplicate molds, and cured at ambient temperature to evaluate the impact of standing bleed water on Saltstone placement. The samples were managed to control drying effects on leachability and hydraulic conductivity by either exposing or capping the samples. The water to premix (w/p) ratio was varied to represent the different processing conditions described in the TTR. Samples were analyzed for density, leachability, and hydraulic conductivity.

In the previous report, ${ }^{5}$ conclusions were made regarding the density and leaching data. A brief summary of those conclusions pertinent to this discussion is included here for convenience:

- Density tends to increase toward the bottom of the samples. This effect is pronounced with excess bleed water.

- Drying of the saltstone during curing leads to decreased Leachability Index (more leaching) for potassium, sodium, rhenium, nitrite, and nitrate.

- There is no noticeable effect on saltstone oxidation/leachability by changing the water to premix ratio (over the range studied), or by pouring into standing water (when tested up to 10 volume percent).

The hydraulic conductivity data presented in this report show that samples cured exposed to the atmosphere had about three orders of magnitude higher hydraulic conductivity than any of the 
other samples. Considering these data, along with the results presented in the previous report, leads to the conclusion that small changes in water to premix ratio and the inclusion of up to 10 volume percent standing water should not be expected to have a detrimental effect on saltstone grout quality. The hydraulic conductivity results further demonstrate that curing in a moist environment is critical to maintaining saltstone quality. 
SRNL-STI-2012-00576

Revision 0

\subsection{References}

1 Liner, K.R., “Saltstone Vault Sheet Drain Installation (U),” CBU-ENG-2003-00103, (2003).

2 Riley, P.J., Tihey, J.R., and Sherburne, D.C., "Engineering Path Forward - Vault 4 Drain Water Collection and Return System Restoration and Actions,” SRR-WSE-2010-00036, (2010).

${ }^{3}$ Staub, A.V., "Impact of Standing Bleed Water on Saltstone Placement," HLW-SSF-TTR-2012-0009, (2012).

${ }^{4}$ Cozzi, A.D., "Task Technical and Quality Assurance Plan for Evaluation of the Impact of Standing Bleed Water on Saltstone Placement,” SRNL-RP-2012-00029, (2012).

${ }^{5}$ Cozzi, A.D. and Pickenheim, B.R., "Impact of Standing Water on Saltstone Placement," SRNS-STI-201200546, (2012).

${ }^{6}$ Reigel, M.M., "Results for the First Quarter 2011 Tank 50 WAC Slurry Sample: Chemical and Radionuclide Contaminant Results,” SRNL-STI-2011-0030, (2011).

${ }^{7}$ Harbour, J.R., Edwards, T.B., Hansen, E.K., and Williams, V.J., "Variability Study for Saltstone," WSRC-TR-2005-00447, (2005).

${ }^{8}$ Flach, G.P., Jordan, J.M., and Whiteside, T., "Numerical Flow and Transport Simulations Supporting the Saltstone Disposal Facility Performance Assessment," SRNL-STI-2009-00115, Revision 0, (2009).

9 "Standard Test Methods for Measurement of Hydraulic Conductivity of Saturated Porous Materials Using a Flexible Wall Permeameter," ASTM International, ASTM D5084 - 10 (Method F). 


\section{Distribution:}

P. M. Almond, 773-43A

J. S. Contardi, 704-S

A. D. Cozzi, 999-W

W. E. Daniel, 999-W

R. E. Eibling, 999-W

S. D. Fink, 773-A

K. M. Fox, 999-W

E. K. Hansen, 999-W

C. C. Herman, 999-W

P. R. Jackson, 703-46A

V. Jain, 704-Z
C. M. Langton, 773-43A

J. N. Leita, 704-Z

S. L. Marra, 773-A

D. H. Miller, 999-W

F. M. Pennebaker, 773-42A

B. R. Pickenheim, 999-W

M. M. Reigel, 999-W

S. P. Simner,

A. V. Staub, 704-Z

K. H. Subramanian, 766-H

Records Administration (EDWS) 